\section{Height Control in Three Pepper Types Treated with Drench-applied Abscisic Acid}

\author{
Christopher J. Biai and José G. Garzon \\ Department of Horticulture, North Carolina State University, Kilgore Hall, \\ Box 7609, Raleigh, NC 27695-7609
}

\author{
Jason A. Osborne \\ Department of Statistics, North Carolina State University, 5238 SAS Hall, \\ Campus Box 8203, Raleigh, NC 27695-8203
}

\author{
Jonathan R. Schultheis \\ Department of Horticulture, North Carolina State University, Kilgore Hall, \\ Box 7609, Raleigh, NC 27695-7609
}

Ronald J. Gehl

Department of Soil Science, North Carolina State University, 455 Research Drive, Mills River, NC 28759

\section{Christopher C. Gunter ${ }^{1}$ \\ Department of Horticulture, North Carolina State University, 230 Kilgore Hall, Box 7609, Raleigh, NC 27695-7609}

Additional index words. Capsicum annuum, ABA, transplant, drench application, cotyledon stage, weekly application, frequencies, timing

\begin{abstract}
Vegetable transplants can have excessive internode elongation before field establishment, producing challenges for the growers using mechanical transplanters to establish their crops. Thus, controlling the height of vegetable transplants before planting could be an advantage for commercial vegetable growers. A greenhouse experiment was conducted in 2008 (Year 1-2008) and 2009 (Year 2-2009) to determine the efficacy of exogenous drench-applied abscisic acid (ABA) applications for height control of transplanted pepper. Three types of pepper (Capsicum annuum L.) were investigated: bell pepper 'Aristotle', Jalapeño 'Grande', and banana pepper 'Pageant'. In this greenhouse study, $10 \mathrm{ABA}$ treatments, based on application frequency and timing, and an untreated control were arranged in a randomized complete block design with six (Year 1-2008) or five (Year 2-2009) replications and were evaluated over an 8-week period each year. Treatments included: single application at Week 1 (cotyledon stage), Week 2, Week 3, and Week 4; double applications were made at Weeks $1+2$, Weeks $2+3$, and Weeks $3+4$; and multiple applications of ABA at Weeks $1+2+3$, Weeks $2+3+4$ and Weeks $1+2+3+4$. All ABA applications were delivered as a drench applied directly to the planting container at a rate of $250 \mathrm{mg} \cdot \mathrm{L}^{-1} \mathrm{ABA}$. Early, single-dose applications (Week 1) were more effective at controlling height than a single dose applied later; a Week 1 application measured during week 5 was $4.1 \mathrm{~cm}$ versus a Week 4 application measured at Week 5, which was $5.7 \mathrm{~cm}$. Multiple ABA applications initiated early (at the cotyledon stage) of 'Aristotle' bell peppers were effective in controlling transplant height compared with any single $\mathrm{ABA}$ application; measured at Week 5, an application at Week $1+2$ was $3.1 \mathrm{~cm}$ compared with the single application treatments from that same measurement date, which ranged from 4.1 to $5.7 \mathrm{~cm}$. Differences among the response of pepper types to ABA application were observed. 'Aristotle' had significant treatment effects even 6 weeks after treatment. 'Pageant' (banana pepper) exhibited an intermediate response with effects lasting only 2 weeks. No significant height reductions resulting from ABA treatment were observed for 'Grande' (Jalapeño pepper). Multiple ABA dose applications initiated at the cotyledon plant growth stage can be used to effectively control transplant height of 'Aristotle' bell pepper seedlings.
\end{abstract}

\footnotetext{
Received for publication 4 Apr. 2011. Accepted for publication 25 June 2011 .

Trade or manufacturers' names mentioned in the article are for information only and do not constitute endorsement, recommendation, or exclusion by North Carolina State University

${ }^{1}$ To whom reprint requests should be addressed; e-mail chris_gunter@ncsu.edu.
}

Transplanting of plug seedlings is the most common planting practice used for pepper production, because it improves stand establishment, shortens the field growing cycle, enhances earliness, and ultimately increases the yield and quality of vegetable crops (Leskovar and Stoffella, 1995). Maintaining uninterrupted growth after transplanting is challenging because seedlings have limited and confined root systems and imperfect rootsoil contact (Burdett, 1990). Biotic and abiotic stressors acting independently or in combination often limit seedling growth and stand establishment (Leskovar and Stoffella, 1995).

Restricted water uptake can lead to sudden and severe plant water deficit, resulting in transplant shock (Nitzsche et al., 1991). Transplant shock can result in the death of the plant or impair the subsequent growth and yield of the surviving seedlings. It most commonly arises when the transpiration demand exceeds the water uptake capacity of the seedlings' root system (Leskovar, 1998). Exogenously applied compounds can trigger partial or complete stomatal closure and thus decrease water loss from leaves. These chemicals include natural plant hormones such as ABA and ABA analogs, which have been used as antitranspirants (Davies and Zhang, 1991). Endogenous ABA is synthesized in the plastids and accumulation in plants occurs when plants are subjected to drought, salt, desiccation, cold, and infection stress (Seo and Koshiba, 2002).

Additionally ABA plays an important role in $\mathrm{CO}_{2}$ and water exchange within the plant and has been of great interest in water conservation in horticultural and agricultural production (Pospisilova et al., 1998; Sharma et al., 2005). Although previously cost-prohibitive, recent improvements in ABA synthesis have made production less expensive on a large commercial scale (Petracek et al., 2005). Abscisic acid application has been used to slow shoot growth (Watts et al., 1981) and has been used to control transplant growth in nurseries (Leskovar and Cantliffe, 1992).

Shoot growth control has also been observed when foliar ABA is applied to adequately watered plants compared with plants exposed to moderate water deficit (Leskovar and Cantliffe, 1992). Abscisic acid also improves plant acclimation to abiotic stresses such as dehydration, cold temperatures, and high salt levels (Levitt, 1980). The effects on drought resistance, plant growth, and development were specific to the crop studied, the ABA analog used, and varied with the mode of application and concentration of chemical applied (Waterer, 2000). Foliar application of relatively dilute solutions of ABA analog PBI 365 produced few negative effects on crop growth and yield under non-stress conditions and maintained yield in moisturestressed conditions (Waterer, 2000). However, use of $\mathrm{ABA}$ in agriculture has been limited because of the rapid metabolism of ABA in plants, the susceptibility of ABA to isomerization to inactive forms by light, and by the high cost of ABA synthesis (Abrams et al., 1997; Flores and Dorffling, 1990).

Genotypes of many crop species vary in their capacity to accumulate ABA in leaves and, hence, may show differences in the sensitivity of developmental processes to changes in soil water content (Henson and Turner, 1991; Pekic et al., 1995). Goreta et al. (2007) found that poblano pepper seedling plant height was significantly shorter when 
sprayed with $2000 \mathrm{mg} \cdot \mathrm{L}^{-1} \mathrm{ABA}$ in a foliar application compared with a control at 3 and $6 \mathrm{~d}$ after transplanting (DAT). Severe water stress caused complete drying and death of control plants and significantly less growth for all other treatments except for ABA-treated seedlings, which exhibited $100 \%$ survival. In a further study by Goreta et al. (2007), stomatal conductance $\left(g_{\mathrm{S}}\right)$ for ABA-treated plants was reduced significantly from a $47 \%$ reduction at 1 DAT to a $60 \%$ reduction 5 DAT compared with untreated plants. Reduced relative growth rate (RGR) of root and all shoot growth components in ABA-treated plants led to $80 \%$ reduction of total RGR compared with control plants.

Foliar exogenous applications of ABA significantly increased stomatal resistance and slowed water use by bell pepper seedlings, resulting in less transplant shock in field experiments (Berkowitz and Rabin, 1988). Berkowitz and Rabin (1988) found that ABA-treated pepper transplants had greater field survival rates than untreated seedlings, which was attributed to reduced $g_{\mathrm{S}}$ and increased leaf water potential. Abscisic acid can increase leaf water potential, survival, and subsequent yield when bell pepper seedlings are transplanted to the field (Berkowitz and Rabin, 1988; Nitzsche et al., 1991).

A compact transplant is desirable because it is more efficient to maintain and transport and easier to transplant than a seedling with elongated internodes (Cerny and Rajapaske, 1999). Growers can control growth by the application of chemical growth regulators to keep the plant short (Cerny and Rajapaske, 1999). Foliar application of other growth regulators such as Sumagic (uniconazole-P; Valent U.S.A. Corporation, Walnut Creek, CA) on ornamental cabbage and kale has been shown to control plant height (Gibson and Whipker, 1999). Flowering azalea plants treated with Sumagic had significantly shorter plant heights (Bir and Conner, 1999). The height control achieved with foliar exogenous applications of ABA may be an alternative to this commercial growth regulator, although limited work has been done investigating ABA use for pepper. The objective of our study was to evaluate the effects of exogenous ABA drench on the height of three types of greenhouse-grown pepper transplants.

\section{Materials and Methods}

Plant material. Three cultivars of peppers were used in this study: Bell pepper 'Aristotle', Jalapeño pepper 'Grande', and Banana pepper 'Pageant'. Pepper seeds (Siegers Seeds, Holland, MI) at one per pot were sown into peatmoss substrate (Growing Mix 2; Conrad Fafard Inc., Agawam, MA) in 473- $\mathrm{cm}^{3}$ containers (Jiffy-Pots $\AA$; Jiffy Products of America, Lorain, $\mathrm{OH}$ ) and placed in a greenhouse on 23 Sept. 2008 (Year 1-2008) and 23 July 2009 (Year 2-2009). After sowing, seeds were covered with peatmoss and were irrigated. Irrigation applications made during the study consisted of water only and were applied on a daily basis by hand until water flowed freely from the bottom
Table 1. Treatment schedule of abscisic acid application to greenhouse pepper seedlings varying frequency and timing in Year 1-2008 and Year 2-2009.

\begin{tabular}{|c|c|c|c|c|c|c|c|c|c|}
\hline \multirow[b]{2}{*}{ Treatment } & \multirow{2}{*}{$\begin{array}{l}\text { Application } \\
\text { timing }\end{array}$} & \multicolumn{4}{|c|}{ Yr 1-2008 } & \multicolumn{4}{|c|}{ Yr 2-2009 } \\
\hline & & \multicolumn{8}{|c|}{ Application date (month/day) } \\
\hline & & & & & & & & & \\
\hline Week 1 & Early & $10 / 7$ & & & & $8 / 6$ & & & \\
\hline Week 2 & Middle & & $10 / 15$ & & & & $8 / 13$ & & \\
\hline Week 3 & Late & & & $10 / 22$ & & & & $8 / 20$ & \\
\hline Week 4 & Late & & & & $10 / 29$ & & & & $8 / 27$ \\
\hline Weeks $1+2$ & Early & $10 / 7$ & $10 / 15$ & & & $8 / 6$ & $8 / 13$ & & \\
\hline Weeks $2+3$ & Middle & & $10 / 15$ & $10 / 22$ & & & $8 / 13$ & $8 / 20$ & \\
\hline Weeks $3+4$ & Late & & & $10 / 22$ & $10 / 29$ & & & $8 / 20$ & $8 / 27$ \\
\hline Weeks $1+2+3$ & Early & $10 / 7$ & $10 / 15$ & $10 / 22$ & & $8 / 6$ & $8 / 13$ & $8 / 20$ & \\
\hline Weeks $2+3+4$ & Middle & & $10 / 15$ & $10 / 22$ & $10 / 29$ & & $8 / 13$ & $8 / 20$ & $8 / 27$ \\
\hline Weeks $1+2+3+4$ & - & $10 / 7$ & $10 / 15$ & $10 / 22$ & $10 / 29$ & $8 / 6$ & $8 / 13$ & $8 / 20$ & $8 / 27$ \\
\hline
\end{tabular}

Table 2. Probability values for height control over two seasons after exogenous abscisic acid drench application to three pepper types. ${ }^{\mathrm{z}}$

\begin{tabular}{lccccccc}
\hline & & \multicolumn{7}{c}{ Weeks after final application } \\
\cline { 3 - 8 } & & 1 & 2 & 3 & 4 & 5 & 6 \\
\cline { 3 - 8 } Cultivar (pepper types) & Yr & \multicolumn{7}{c}{$P$ values } \\
\hline Aristotle (bell) & 1 & $<0.0001$ & 0.0021 & 0.0081 & 0.0231 & NS & - \\
Pageant (banana) & 2 & 0.0209 & 0.0070 & 0.0050 & 0.0045 & 0.0069 & 0.014 \\
& 1 & 0.0567 & 0.0130 & NS & NS & NS & - \\
Grande (Jalapeño) & 2 & 0.0258 & NS & NS & NS & NS & NS \\
& 1 & NS & NS & NS & NS & NS & - \\
& 2 & NS & NS & NS & NS & NS & NS \\
\hline
\end{tabular}

${ }^{2}$ Significance is shown by week for weeks 1 to 6 after final applications of abscisic acid in Year 1-2008 and Year 2-2009.

NS $=$ non-significantly different at $P \leq 0.05$.

Table 3. Mean plant height of Capsicum annuum cv. Aristotle by the week of the experiment after the application of abscisic acid in Year 1-2008.

\begin{tabular}{|c|c|c|c|c|}
\hline \multirow[b]{3}{*}{ Treatment } & \multicolumn{4}{|c|}{ Week } \\
\hline & 5 & 6 & 7 & 8 \\
\hline & \multicolumn{4}{|c|}{ Mean plant ht $(\mathrm{cm})$} \\
\hline Untreated control & $5.1 \mathrm{ab}^{\mathrm{z}}$ & $6.4 \mathrm{ab}$ & $8.4 \mathrm{abc}$ & $9.5 \mathrm{ab}$ \\
\hline Week 1 & $4.1 \mathrm{cde}$ & $5.1 \mathrm{bc}$ & $7.6 \mathrm{cde}$ & $9.1 \mathrm{abc}$ \\
\hline Week 2 & $4.7 \mathrm{bc}$ & $5.9 \mathrm{ab}$ & $8.2 \mathrm{abc}$ & $10.5 \mathrm{a}$ \\
\hline Week 3 & $4.9 \mathrm{abc}$ & $6.1 \mathrm{ab}$ & $8.7 \mathrm{abc}$ & $10.6 \mathrm{a}$ \\
\hline Week 4 & $5.7 \mathrm{a}$ & $6.9 \mathrm{a}$ & $8.9 \mathrm{ab}$ & $10.7 \mathrm{a}$ \\
\hline Week $1+2$ & $3.1 \mathrm{e}$ & $4.3 \mathrm{c}$ & $6.1 \mathrm{e}$ & $7.8 \mathrm{bc}$ \\
\hline Week $2+3$ & $4.6 \mathrm{bc}$ & $6.3 \mathrm{ab}$ & $9.5 \mathrm{a}$ & $11.3 \mathrm{a}$ \\
\hline Week $3+4$ & $4.8 \mathrm{abc}$ & $5.8 \mathrm{ab}$ & $8.1 \mathrm{abcd}$ & $9.8 \mathrm{ab}$ \\
\hline Week $1+2+3$ & $4.0 \mathrm{cde}$ & $5.2 \mathrm{bc}$ & 7.7 abcde & $10.1 \mathrm{ab}$ \\
\hline Week $2+3+4$ & $4.1 \mathrm{~cd}$ & $5.1 \mathrm{bc}$ & $6.9 \mathrm{cde}$ & $9.5 \mathrm{abc}$ \\
\hline Week $1+2+3+4$ & $3.5 \mathrm{de}$ & $4.4 \mathrm{c}$ & $6.3 \mathrm{de}$ & $7.2 \mathrm{c}$ \\
\hline $\operatorname{Pr}>F$ & 0.0002 & 0.0053 & 0.0156 & 0.0315 \\
\hline Least significant difference & 0.95 & 1.30 & 1.84 & 2.35 \\
\hline
\end{tabular}

${ }^{\mathrm{z}}$ Mean plant heights with the same letter in a given column are not different at $P \leq 0.05$.

Table 4. Mean plant height of Capsicum annuum cv. Aristotle by the week of the experiment after the application of abscisic acid in Year 2-2009.

\begin{tabular}{|c|c|c|c|c|}
\hline \multirow[b]{3}{*}{ Treatment } & \multicolumn{4}{|c|}{ Week } \\
\hline & 5 & 6 & 7 & 8 \\
\hline & \multicolumn{4}{|c|}{ Mean plant ht $(\mathrm{cm})$} \\
\hline Control & $6.6 \mathrm{a}^{\mathrm{z}}$ & $8.3 \mathrm{abc}$ & $9.1 \mathrm{ab}$ & $9.7 a b c$ \\
\hline Week 1 & $5.2 \mathrm{abc}$ & $7.0 \mathrm{abcd}$ & $8.0 \mathrm{bc}$ & $8.6 \mathrm{abcd}$ \\
\hline Week 2 & $5.2 \mathrm{abc}$ & $6.9 \mathrm{a}$ & $7.6 \mathrm{bc}$ & $8.2 \mathrm{bcde}$ \\
\hline Week 3 & $6.4 \mathrm{a}$ & $8.6 \mathrm{a}$ & $10.2 \mathrm{ab}$ & $10.9 \mathrm{a}$ \\
\hline Week 4 & $6.4 \mathrm{ab}$ & $8.3 \mathrm{ab}$ & $9.3 \mathrm{ab}$ & $9.9 \mathrm{ab}$ \\
\hline Week $1+2$ & $5.9 \mathrm{ab}$ & $8.0 \mathrm{abc}$ & $9.1 \mathrm{ab}$ & $9.9 \mathrm{ab}$ \\
\hline Week $2+3$ & $5.2 \mathrm{abc}$ & $7.0 \mathrm{abcd}$ & $7.9 \mathrm{bc}$ & $8.7 \mathrm{abcd}$ \\
\hline Week $3+4$ & $5.2 \mathrm{abc}$ & $6.6 \mathrm{~cd}$ & $7.4 \mathrm{bc}$ & 7.9 bcde \\
\hline Week $1+2+3$ & $4.1 \mathrm{c}$ & $5.4 \mathrm{cde}$ & $6.2 \mathrm{c}$ & $6.9 \mathrm{de}$ \\
\hline Week $2+3+4$ & $4.8 \mathrm{bc}$ & $6.1 \mathrm{cde}$ & $6.8 \mathrm{c}$ & $7.4 \mathrm{cde}$ \\
\hline Week $1+2+3+4$ & $3.9 \mathrm{e}$ & $4.9 \mathrm{~d}$ & $5.8 \mathrm{c}$ & $6.2 \mathrm{e}$ \\
\hline $\operatorname{Pr}>F$ & 0.0434 & 0.0199 & 0.0175 & 0.0154 \\
\hline Least significant difference & 1.65 & 2.02 & 2.24 & 2.33 \\
\hline
\end{tabular}

${ }^{\mathrm{z}}$ Mean plant heights with the same letter in a given column are not different at $P \leq 0.05$. 
of pots. Liquid fertilizer applications were made by mixing $8 \mathrm{~g}$ of soluble fertilizer $20 \mathrm{~N}-$ 4.4P-16.6K (Scotts Miracle-Gro Products, Marysville, $\mathrm{OH}$ ) with $3.75 \mathrm{~L}$ of water. Fertilizer applications were made three times during the season, supplying each plant with $50 \mathrm{~mL}$ of the liquid fertilizer at a concentration of 100 $\mathrm{mg} \cdot \mathrm{L}^{-1} \mathrm{~N}$ as a drench. Both experiments were conducted in a glass greenhouse in Raleigh, $\mathrm{NC}$, at $35^{\circ} \mathrm{N}$ latitude. Plants were grown at $18^{\circ} \mathrm{C}$ day and $15^{\circ} \mathrm{C}$ night temperatures. No supplemental lighting was used during this study.

Abscisic acid application. Drench applications of water with ABA, VBC-30101 (10\% ABA; Valent U.S.A. Corporation), were applied in $50-\mathrm{mL}$ doses $(\approx 10 \%$ of total pot volume) at an application rate of $250 \mathrm{mg} \cdot \mathrm{L}^{-1}$ ABA. Treatments were based on frequency and timing of ABA applications (Table 1). Treatment based on frequency was as follows: single application at Week 1 (cotyledon stage), Week 2 (cotyledon stage plus 1 week), Week 3 (cotyledon stage plus 2 weeks), and Week 4 (cotyledon stage plus 3 weeks); double applications were made at Weeks 1 and $2(1+2)$, Weeks 2 and $3(2+3)$, and Weeks 3 and $4(3+$ $4)$; and multiple application treatments received $\mathrm{ABA}$ at Weeks 1,2 , and $3(1+2+3)$, Weeks 2,3 , and $4(2+3+4)$, and Weeks 1,2 , 3 , and $4(1+2+3+4)$. Treatments based on timing were as follows: early applications at Week 1 , Weeks 1 and $2(1+2)$, Weeks 1,2 , and $3(1+2+3)$; midtiming applications made at Week 2 (cotyledon stage +1 week), Weeks 2 and $3(2+3)$, Weeks 2,3 , and $4(2+3+4)$; and late application treatments received $\mathrm{ABA}$ at Week 3 , Weeks 3 and $4(3+4)$, and Week 4 . Because the Weeks $1+2+3+4$ treatment received an application every week, it was omitted from the timing-based analysis. Repeated measurements were made on each plant within each block; this constitutes a randomized complete block split-plot design with ABA application treatment as the single whole-plot factor (with 11 levels) and time as the split-plot factor. All 11 treatments were arranged in a randomized complete block (split-plot in time) study with six (Year 1-2008) or five (Year 22009) replications. In both years, height data were collected weekly for 8 weeks beginning 7 Oct. 2008 and 18 Aug. 2009. Plant height was measured from the substrate surface to the shoot apex.

Statistical analysis. A mixed-effects linear model was fit using the PROC MIXED procedure of the SAS statistical software package (Version 9.1.3, SAS Institute, Cary, NC) to investigate the effects of the various frequencies and timings of ABA application on plant heights, which were measured repeatedly over time. The factors in this study were frequency (with levels single, double, or multiple), timing (with levels early, middle, or late), and the control comparison. Factorial effects for frequency and timing, nested within control, and weeks after final application were then included in a mixed-effects model with random effects for block $\times$ treatment interaction. In accordance with this design, random effects for block and block $\times$ ABA application in- teraction were included in the mixed-effects model. The design does not include all combinations of frequency and timing, so that effects for these factors are necessarily confounded to some degree. All pairwise comparisons among the 11 treatment means were conducted separately for each week. Means were separated using Fisher's test of least significant difference.

\section{Results and Discussion}

The effect of ABA on plant height differed among the pepper cultivars and types with 'Aristotle' being highly responsive (shorter plant height versus the control) and continuing to show differences even after 6 weeks of data collection, whereas 'Pageant' had an initial response, but statistically significant treatment differences were not evident by the second week of data collection. 'Grande' did not have a significant height response among treatments in either year of the study (Table 2). The differences we observed among pepper cultivars were in accordance to trends previously reported for other plant species (Blanchard et al., 2007; Churchill et al., 1998; Sharma et al., 2006). Li et al. (2004) reported that different species of Populus davidiana responded differently to exogenous ABA application. Accordingly, data presented here will be specific to 'Aristotle' in Week 5 (1 week after final treatment) because this cultivar was most responsive to ABA treatment.

In Year 1-2008 (Table 3) and Year 2-2009 (Table 4), multiple ABA drench applications resulted in significantly shorter plant heights compared with the untreated control during Weeks 5 through 8 of the study. These reductions ranged from $24 \%$ to $40 \%$ depending on the measurement week and year. This is in agreement with previous work in which bell pepper transplants (Leskovar and Cantliffe, 1992) and two Populus species (Yin et al., 2004) treated with foliar ABA had shorter

Table 5. Frequency effect on mean plant height of Capsicum annuum cv. Aristotle by the week of the experiment after the application of abscisic acid in Year 1-2008 and Year 2-2009.

\begin{tabular}{|c|c|c|c|c|c|c|c|c|}
\hline \multirow[b]{3}{*}{ Frequency } & \multicolumn{8}{|c|}{ Week } \\
\hline & \multicolumn{4}{|c|}{ Yr 1-2008 } & \multicolumn{4}{|c|}{ Yr 2-2009 } \\
\hline & 5 & 6 & 7 & 8 & 5 & 6 & 7 & 8 \\
\hline Control & $5.1 \mathrm{a}^{\mathrm{z}}$ & $6.3 \mathrm{a}$ & $8.4 \mathrm{a}$ & $9.5 \mathrm{ab}$ & $6.6 \mathrm{a}$ & $8.3 \mathrm{a}$ & $9.1 \mathrm{a}$ & $9.7 \mathrm{a}$ \\
\hline Single & $4.8 \mathrm{a}$ & $6.0 \mathrm{a}$ & $8.4 \mathrm{a}$ & $10.2 \mathrm{a}$ & $5.8 \mathrm{a}$ & $7.7 \mathrm{a}$ & $8.8 \mathrm{a}$ & $9.4 \mathrm{a}$ \\
\hline Double & $4.2 \mathrm{ab}$ & $5.5 \mathrm{ab}$ & $7.9 \mathrm{ab}$ & $9.6 \mathrm{ab}$ & $5.4 \mathrm{ab}$ & $7.2 \mathrm{a}$ & $8.1 \mathrm{a}$ & $8.8 \mathrm{a}$ \\
\hline Multiple & $3.8 \mathrm{~b}$ & $4.9 \mathrm{~b}$ & $6.9 \mathrm{~b}$ & $8.9 \mathrm{~b}$ & $4.2 \mathrm{~b}$ & $5.4 \mathrm{~b}$ & $6.3 \mathrm{~b}$ & $6.8 \mathrm{~b}$ \\
\hline
\end{tabular}

${ }^{\mathrm{z}}$ Simple effect comparisons of week $\times$ frequency least squares means of plant heights with the same letter in a given column are not different at $P \leq 0.05$.

Table 6. Timing effect on mean plant height of Capsicum annuum cv. Aristotle by week of the experiment following the application of abscisic acid in Year 1-2008 and Year 2-2009.

\begin{tabular}{|c|c|c|c|c|c|c|c|c|}
\hline \multirow[b]{3}{*}{ Timing } & \multicolumn{8}{|c|}{ Week } \\
\hline & \multicolumn{4}{|c|}{ Yr 1-2008 } & \multicolumn{4}{|c|}{ Yr 2-2009 } \\
\hline & 5 & 6 & 7 & 8 & 5 & 6 & 7 & 8 \\
\hline Control & $5.1 \mathrm{a}^{\mathrm{z}}$ & $6.3 \mathrm{a}$ & $8.4 \mathrm{a}$ & $9.5 \mathrm{ab}$ & 6.6 & 8.3 & 9.1 & 9.7 \\
\hline Early & $3.7 \mathrm{~b}$ & $4.7 \mathrm{~b}$ & $6.9 \mathrm{~b}$ & $8.5 \mathrm{~b}$ & 4.8 & 6.3 & 7.3 & 7.9 \\
\hline Middle & $4.6 \mathrm{a}$ & $5.8 \mathrm{a}$ & $8.3 \mathrm{a}$ & $10.5 \mathrm{a}$ & 5.4 & 7.1 & 8.1 & 8.8 \\
\hline Late & $5.3 \mathrm{a}$ & $6.3 \mathrm{a}$ & $8.5 \mathrm{a}$ & $10.2 \mathrm{a}$ & 5.8 & 7.5 & 8.3 & 8.9 \\
\hline
\end{tabular}

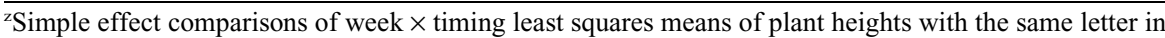
a given column are not different at $P \leq 0.05$. plants compared with untreated control plants. sudy, multiple applications were genat reducing plant height (Tables 3 and 4). An early single application at Week 1 tended to be more effective at controlling height than applications applied at Week 3 and 4. reported by Ma et al. (2008) in two Malus species treated with foliar-applied ABA.

Based on the differences among treatand timing factors was evident and this relationship was included in the model so that tiple application frequency resulted in significantly shorter plant heights compared with a Results for Year 2-2009 were consistent with exception being Week 8 in which a single application resulted in shorter plants than if no 1-2008 (Table 6) indicated that transplants with an early application of ABA were ceiving later application timings when measured at Weeks 5, 6, 7, and 8 after final ABA application. In Year 2-2009, although not significantly different, treatments comparisons trend as in Year 1-2008.

Although frequency and timing-by-year interaction were significant between years, similar responses to most treatments suginsight and keys into these treatment effects. that end, an expanded version of the linea year $\times$ timing and year $\times$ treatment interactions was tested. Data for both years were pooled for frequency analysis (Fig. 1A) and single application when measured at Weeks 5 , the Year 1-2008 findings with the same treat- 

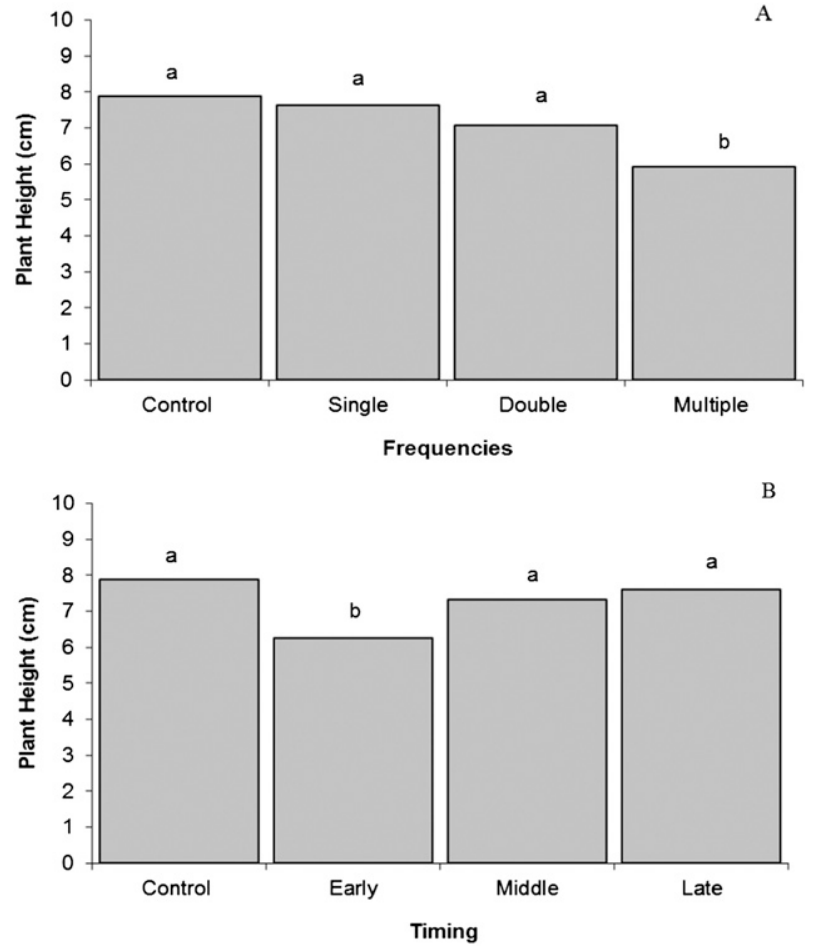

Fig. 1. Mean plant height of C. annuum cv. Aristotle by frequencies (A) and timing (B) for pooled data (Year 1-2008 and Year 2-2009). Differences of least square means of plant heights with the same letter are not significantly different at $P \leq 0.05$.

indicate that multiple application frequency resulted in shorter plant height compared with single- and double-application frequency at Weeks 5, 6, 7, and 8 after final ABA application. The height of the peppers receiving multiple applications was $30 \%$ less than the control treatment plants. Analysis of height response to application timing (Fig. 1B) indicated that plants receiving relatively early applications were significantly shorter than plants receiving later applications. For example, those seedlings receiving an early application were $\approx 30 \%$ shorter than the untreated control seedlings. Although the reported marginal means for each timing treatment are estimates of the mean response for an average year, the SE used to quantify the uncertainty in this estimate reflects all resources of variability in the model, including year-to-year variability and year $\times$ timing interaction.

Multiple drench applications of $250 \mathrm{mg} \cdot \mathrm{L}^{-1}$ $\mathrm{ABA}$, beginning at the cotyledon stage and continuing for 3 to 4 weeks, were more effective at controlling plant height than any single weekly application regardless of timing. Application of ABA to pepper transplants can be an important scheduling tool for pepper transplant producers. Plants receiving early applications tended to be shorter than those receiving late application (Fig. 1B).

In conclusion, the three pepper cultivars responded differently to exogenous drench ABA application. Multiple applications initiated at the cotyledon stage controlled plant height of 'Aristotle' bell pepper seedlings. No phytotoxicity was observed with the drench applications in this study at the rate of 250 $\mathrm{mg} \cdot \mathrm{L}^{-1}$. Future work in this area may include a more detailed examination of the response of different pepper cultivars to exogenous ABA, both foliar and drench-applied. Pageant and Grande cultivars had limited or no response to exogenous $\mathrm{ABA}$, which may be attributed to the rate of ABA used in this study. An exploration of differences in pepper cultivars using greater rates of product may be beneficial. Furthermore, it is possible that the lack of response is the result of differences in sensitivity at various stages of growth.

\section{Literature Cited}

Abrams, S.R., P.A. Rose, A.J. Cutler, J.J. Balsevich, and M.K. Walker-Simmons. 1997. 8'Methylene ABA: An effective and persistent analog of abscisic acid. Plant Physiol. 144:89-97.

Berkowitz, G.A. and J. Rabin. 1988. Antitranspirant associated abscisic acid effects on the water relations and yield of transplanted bell peppers. Plant Physiol. 86:329-331.

Bir, R.E. and J.L. Conner. 1999. Container grown azalea response to sumagic sprays. Southern Nursery Association Research Conference. 44: 274-276.

Blanchard, M.G., L.A. Newton, E.S. Runkle, and D. Woodlard. 2007. Exogenous applications of abscisic acid improved the postharvest drought tolerance of several annual bedding plants. Acta Hort. 755:127-132.

Burdett, A.N. 1990. Physiological processes in plantation establishment and the development of specifications for forest planting stock. Can. J. For. Res. 20:415-427.

Cerny, T.A. and N.C. Rajapaske. 1999. Regulation of bedding plant growth by photoselective greenhouse covers. Southern Nursery Association Research Conference. 44:270-273.
Churchill, G.C., M.J.T. Reaney, S.R. Abrams, and L.V. Gusta. 1998. Effects of abscisic acid and abscisic acid analogs on the induction of freezing tolerance of winter rye (Secale cereale L.) seedlings. J. Plant Growth Regul. 25:35-45.

Davies, W.J. and J.H. Zhang. 1991. Root signals and the regulation of growth and development of plants in drying soil. Annu. Rev. Plant Physiol. Plant Mol. Biol. 42:55-76.

Flores, A. and K. Dorffling. 1990. A comparative study of the effects of abscisic acid and new terpenoid abscisic acid analogs on plant physiological processes. J. Plant Growth Regul. 9:133-139.

Gibson, J.L. and B.E. Whipker. 1999. The effect of B-Nine, Bonzi, and Sumagic on the growth of ornamental cabbage and kale. Southern Nursery Association Research Conference. 44:281-283.

Goreta, S., D.I. Leskovar, and J.L. Jifon. 2007. Gas exchange, water status, and growth of pepper seedlings exposed to transient water deficit stress are differentially altered by antitranspirants. J. Amer. Soc. Hort. Sci. 132: 603-610.

Henson, I.E. and N.C. Turner. 1991. Stomatal responses to abscisic acid in three lupin species. New Phytol. 117:529-534.

Leskovar, D.I. 1998. Root and shoot modification by irrigation. Proc. of the workshop on transplant production and performance. Fifth national symposium on stand establishment. Ohio State University, Columbus, OH, May 1997.

Leskovar, D.I. and D.J. Cantliffe. 1992. Pepper seedling growth-response to drought stress and exogenous abscisic acid. J. Amer. Soc. Hort. Sci. 117:389-393.

Leskovar, D.I. and P.J. Stoffella. 1995. Vegetables seedling root systems: Morphology, development and importance. HortScience 30: 1153-1159.

Levitt, J. 1980. Responses of plants to environmental stresses. 2nd Ed. Vols. 1 \& 2. Academic Press, New York, NY.

Li, C., C. Yin, and S. Liu. 2004. Different responses of two contrasting Populus davidiana populations to exogenous abscisic acid application. Environ. Exp. Bot. 51:237-246.

Ma, X., M. Fengwang, M. Yinfa, M. Yuhua, and S. Huairui. 2008. Morphology and physiological responses of two contrasting Malus species to exogenous abscisic acid application. Plant Growth Regulat. 56:77-87.

Nitzsche, P., G.A. Berkowitz, and J. Rabin. 1991. Development of a seedling-applied antitranspirant formulation to enhance water status, growth and yield of transplanted pepper. J. Amer. Soc. Hort. Sci. 116:405-411.

Pekic, S., R. Stikic, V. Andjelkovic, M. Ivanovic, and S. Quarrie. 1995. Characterization of maize lines differing in leaf abscisic acid content in the field: I. Abscisic acid physiology. Ann. Bot. (Lond.) 75:67-73.

Petracek, P.D., D. Woodlard, R. Menendez, and P. Warrior. 2005. Challenges for the commercial development of s-abscisic acid (ABA). Proc. 2005 Annual Conf. Plant Growth Regulation Soc. Amer. 7-9. 24 Feb. 2009. <http:// www. pgrsa.org/2005_Proceedings/ papers/ 003.pdf $>$.

Pospisilova, J., N. Wilhelmova, H. Synkova, J. Catsky, D. Krebs, I. Ticha, B. Hanakova, and J. Snopek. 1998. Acclimation of tobacco plantlets to ex vitro conditions as affected by application of abscisic acid. J. Expt. Bot. 49:863-869. 
Seo, M. and T. Koshiba. 2002. Complex regulation of ABA biosynthesis in plants. Trends Plant Sci. 7:41-48.

Sharma, N., S.R. Abrams, and D.R. Waterer. 2005. Uptake, movement, activity, and persistence of an abscisic acid analog (8' acetylene ABA methyl ester) in marigold and tomato. J. Plant Growth Regul. 24:28-35.
Sharma, N., S.R. Abrams, and D.R. Waterer. 2006. Evaluation of abscisic acid analogs as holding agents in bedding plant seedlings. HortTechnology 16:71-76.

Waterer, D. 2000. Evaluation of ABA analogs for enhancement of stress tolerance in high-value horticultural crops. Saskatchewan Agriculture and Food-Agriculture Development Fund Report. p. 48
Watts, S., J.L. Rodriguez, S.E. Evans, and W.J. Davies. 1981. Root and shoot growth of plants treated with abscisic acid. Ann. Bot. (Lond.) 47:595-602.

Yin, C., D. Baoli, W. Xiang, and L. Chunyang. 2004. Morphological and physiological responses of two contrasting poplar species to drought stress and exogenous abscisic acid application. Plant Sci. 167:1091-1097. 